\title{
Exploring the Implementation Model of Islamic Law in Indonesia
}

\author{
Ahmad Rajafi ${ }^{1}$, Salma$^{2}$, Naili Adilah Hamhij ${ }^{3}$, Suyatno Ladiqi ${ }^{4}$
}

\begin{abstract}
Exploring the Implementation Model of Islamic Law in Indonesia. This article aims to explore the models of application of Islamic law in Indonesia by the State, ranging from traditional to modern, including aspects of reform. This research found the fact that at the beginning of the entry of Islam to the archipelago, the propagators of Islam had partially applied Islamic law, especially after the establishment of Islamic kingdoms in several areas. However, after the establishment of the Unitary State of the Republic of Indonesia, the model of applying Islamic law underwent renewal with formalistic, religious-ethics, and convergence models. Unfortunately, in the production stage, the implementation encountered many obstacles because it had to enter the realm of practical politics. Therefore, its development continues to move partially, such as the issuance of the Marriage Law, Zakat, Hajj, and so on, including through material review in the Constitutional Court.
\end{abstract}

Keywords: Islamic law, Indonesia, implementation, legal reform.

Abstrak: Menggali Model Implementasi Hukum Islam di Indonesia. Artikel ini bertujuan untuk menelusuri model-model penerapan hukum Islam di Indonesia yang dilakukan oleh Negara, mulai dari yang sifatnya tradisional hingga modern, termasuk aspek pembaruannya. Penelitian ini menemukan fakta bahwa pada awal masuknya Islam ke Nusantara, para penyebar Islam telah menerapkan hukum Islam secara parsial, terutama setelah berdirinya kerajaan-kerajaan Islam di beberapa daerah. Namun setelah berdirinya Negara Kesatuan Republik Indonesia, model penerapan hukum Islam mengalami pembaruan dengan model formalistik, religo-ethics, dan konvergensi. Sayangnya, dalam tahapan produksinya, penerapan itu banyak mengalami kendala karena harus masuk ke ranah politik praktis. Oleh karena itu, pderkembangannya tetap bergerak secara parsial, seperti lahirnya Undang-undang Perkawinan, Zakat, Haji, dan lain sebagainya, termasuk melalui jalur uji materi di Mahkamah Konstitusi.

Kata Kunci: hukum Islam, Indonesia, implementasi, pembaruan hukum

\footnotetext{
${ }^{1,2}$ Institut Agama Islam Negeri Manado, Indonesia

${ }^{3}$ Universitas Islam Negeri Raden Intan Lampung, Indonesia

${ }^{4}$ Universiti Sultan Zainal Abidin Terengganu, Malaysia

E-mail: ${ }^{1}$ ahmad.rajafi@gmail.com, ${ }^{2}$ salma.mursyid@iain-manado.ac.id, ${ }^{3}$ nayhamhij@gmail.com,

4yatno.ladiqi@gmail.com
} 


\section{Introduction}

Indonesia as the country with the world's largest Muslim population has an important role in the politics towards the formation of law, which is inspired by the religious norm, and other customary and external norms. Humans create norms for their needs and goodness. They must be able to formulate the ideas and values that can be embodied in social life both personally and collectively.

In Islam contextually, the inspiration is echoing from al-Qur'an and al-Hadith, it is known as ash-Shari'ah or Islamic law. For Muslims, all movements and thoughts must be in line with the Shari'ah. At least, five verses specifically emphasize this obligation, namely; QS. Ali Imran (3): 32, QS. an-Nisa '(4): 59, QS. al-Anfal (8): 20, QS. an-Nur (24): 54, and QS. Muhammad (47): 33.

This obligation also applies to Muslims in the archipelago, and unfortunately, its implementation is still focused on the private part which is presented individually by Islamic preachers based on their education and interpretation from their teachers. In this aspect, the progression of the law seems to be stagnant because the interpretations (aqwäl and manhaj) of the Muslim scholars are considered as holy persons so they should not be evaluated and revised. Whereas, the purpose of presenting Islamic law before humans living is, as the emergence of synergy between God's will which has been stated in the Qur'an and the visual of the universe and the prophet Muhammad's biography with the spirit of seeking goodness (benefit) that will be carried out by humans after the passing of the Prophet Muhammad saw.

History shows that fiqh or Islamic law was initially a dynamic and innovative power, which is started with the presence of various understandings (madzāhib) of Islamic thinkers with their responsive and progressive style of knowledge and regionalism. However, in the initial context in the archipelago, it seems that Islamic law has stagnated because of the dominance of one mazhab of thought and it seems hard to deny the thought of other mazhab as a variety of law.

After independence, the Muslim scholars in Indonesia participated 
in Indonesian independence and formulated legal norms afterwards, they started to get their moment to see the diversity of Islamic thought developing in the world. As a result, when the law on marriage in the Old Order was formulated, it had a long and unfinished debate, only in the early days of the New Order, the Law on marriage could be realized with other implementing regulations in the form of Compilation of Islamic Law.

Besides, after Indonesia entered the Reformation, the cracks of Islamic thought became more progressive and productive by criticizing not only the ulama's thought but also the religious authority. In that era, criticism (al-naqdu) the religious authority seemed to be an obligation for Islamic thinkers to reach the essential side and open up the historical towards a perfect hadharah an-nash through a dialogue process with Divine revelation, ${ }^{1}$ such a born Counter Legal Draft of Islamic laws in Indonesia.

That is a brief history of the movement of the application of Islamic law in Indonesia, which became the main idea in writing this paper. But the problem is, when all these movements are considered as a legal reformation, then what are the direction and movement of Islamic law reform? This is the urgency of this paper, where the aim is to describe fully the direction and motion of Islamic law renewal in Indonesia by examining the model of implementing Islamic law and the spirit of its innovation.

\section{Indonesian Model of Islamic Law}

Islamic law in Indonesia is classified as living law, even Islamic law has been a state law since the days of the Islamic Mataram kingdom (1613-1745 AD) under the rule of Sultan Agung. ${ }^{2}$ However,

${ }^{1}$ Ahmad Rajafi, "Islam dan Kearfian Lokal: Pembaruan Hukum Keluarga di Indonesia Model Inkulturasi Wahyu dan Budaya Lokal," Akademika: Jurnal Pemikiran Islam, 21, no. 1 (Juni 2016): 73.

2 Bustanul Arifin, "Membangun Ilmu Hukum Indonesia," dalam Hukum Islam di Indonesia: Perspektif Muhammadiyah dan NU (Jakarta: Universitas Yarsi, 1999), xi. 
changes in perception and implementation occurred when the Dutch entered Indonesia and made an assessment of the implementation of Islamic law. The conception is; First, the Dutch introduced and practiced the theory of receptio in complexu, in which Muslims applied Islamic law. Secondly, the receptie theory emerged and was led by Snouck Hurgronje, where Islamic law was stated when it became part of customary law. According to Ichtianto as quoted by Maftukhatusolikhah, ${ }^{3}$ the theory of the application of Islamic law above in the Dutch era, due to their lack of understanding of the situation of indigenous peoples, especially Muslims, as a result, this attitude has harmed the government itself.

Changes in the acceptance and implementation of Islamic law in Indonesia_as explained above-are certainly part of a renewed understanding of the law, it continuously able to find buildings that are more established and sturdy in implementing Islamic law. The model of implementation of Islamic law in Indonesia consists of three models, namely the formalistic model, religious-ethics, and the convergence model, which is formalistic of cultural-based. ${ }^{4}$

\section{Formalistic Model}

Before explaining this model, it is important to explain the position of Islamic law in the frame of national law, since Islamic law is one of the foreign products which entered Indonesia. Starting by reading on Kelsen's theory of pure theory of law which emphasizes the distinction between empirical law and transcendental justice by not including it in the legal studies section, so that the law according to him is purely a human experience. ${ }^{5}$ Therefore, to realize the theory in creating an ideal

${ }^{3}$ Maftukhatusolikhah, "Qanunisasi Hukum Islam: Suatu Tinjauan Filsafat Hukum," Medina-Te, 3, no. 1 (Juni 2007): 2.

${ }^{4}$ Ahmad Rajafi, "Inkulturasi Wahyu dan Budaya Lokal Serta Implikasinya Terhadap Pembaharuan Hukum Keluarga di Indonesia” (Disertasi, IAIN Raden Intan, Lampung, 2015). $145-154$

${ }^{5}$ Jimly Asshiddiqie dan Ali Safa'at, Teori Hans Kelsen tentang Hukum (Jakarta: Sekretariat Jenderal \& Kepaniteraan Mahkamah Konstitusi RI, 2006), 11. 
legal state, Kalsen in his other book presents stufen theory ${ }^{6}$ or Hans Kelsen's Stairs Theory.

Based on the big concept from Kelsen, in Indonesian National Law frame, the Basic Rules (red. KD) in the formation of law is Pancasila, and in the first precept, it is stated that the general norm is a religious foundation, namely "God Almighty", which confirms that Indonesia neither a secular state nor a religious state, ${ }^{7}$ but the values contained in the first precept indicates that this country recognizes religion. ${ }^{8}$

The descendants of $\mathrm{KD}$ are the Constitution, wherein the third century the Preamble of the 1945 Constitution was stated "by the blessing of the grace of Allah Almighty ...", spelled out in Article 29 of the Constitution which guarantees the existence of religion in the state. Thus, it can be seen that the Indonesian have accepted religious teachings adopted by their society even though these teachings come from foreigners, including Islam from the Arab.

Regarding this matter, Bachsan Mustafa explained that customary law originating from foreign countries was perceived in Indonesian law as the original law of a nation, by acculturation. ${ }^{9}$ In formulating the law that originated from Islam, a country established the Department of Religion in 1946 which changed its name to the Ministry of Religion in 2010 as a form of practice of the KD and the 1945 Constitution above, hence, this was born Islamic legal products such as Law 1 / 74 concerning Marriage, Law 38/99 concerning Management of Zakat, Law 41/04 concerning Waqf, and Law 13/08 concerning the Organization of Hajj.

The formalization of Islamic law is the middle way that is presented by the state in responding to two poles of Islamic thought

${ }^{6}$ Hans Kelsen, General Theory of Law and State (New York: Reissued, 1961).

${ }^{7}$ Krissantono (ed.), Pandangan Presiden Soeharto tentang Pancasila (Jakarta: Yayasan Proklamasi CSIS, 1980), 27.

${ }^{8}$ Krissantono (ed.), 26.

${ }^{9}$ Bachsan Mustafa, Sistem Hukum Indonesia, II (Bandung: Remadja Karya, 1985), 18. 
and movement in Indonesia which always attracts each other, between ideological Islamic groups and the understanding of Shari'ah formalism or legalism in total with Islamic groups as religions -ethics who reject the formalization of shari'ah even the involvement of religion in the context of state life.

The solution is by accepting the formalization of Islamic law but it is not just on private objects, and according to Masykuri Abdillah, the orientation of the solution above is more realistic and more appropriate in Indonesia nowadays. ${ }^{10}$ However, in the concept of formalizing Islamic law which is ideological, making Islamic law just as a sub-ideology is not justified, because it is contrary to the rule of Islam which commands its people to be religious fully, see QS. al-Baqarah (2): 208 and QS. al-Maidah (5): 44,45,47.

Through these proofs of Qur'an, formalist groups want to establish their own Islamic country or make Indonesia is as a part of the Islamic caliphate. In this concept, politics, and Islam walk in the same way. ${ }^{11}$ so that they were very eager to re-enter the sentence that was considered to be abrogated in the first principle of the Pancasila or to return the contents of the Jakarta Charter as the $\mathrm{KD}$ of the Indonesian nation, that is "with the obligation to practice Islamic law for its adherents". However, in the legal politics of Indonesia, this ideological movement has never been able to express the ideology of their formalism, which exists and is accepted by this nation, all kinds of law that do within society, both customary and Islamic, it is not permissible to contradict the 1945 Constitution.

In terms of Islamic law, construction has an independent position that is no longer relied on by his application to customary law (receptio a contrario $)^{12}$ It is no longer believed by Snoch Hurgronje as his

${ }^{10}$ Masykuri Abdillah, "Wacana Formalisasi Syariat Islam," dalam Formalisasi Syariat Islam di Indonesia: Sebuah Pergulatan yang Tak Pernah Tuntas (Jakarta: Renaisan, 2007), 7.

${ }^{11}$ Muhammad Mustaqim, "Fundamentalisme Islam dan Tantangan Negara-Bangsa (NationState)," Jurnal Abidin Media Dielektika Ilmu Islam 3, no. 2 (Desember 2011): 318.

${ }^{12}$ Nur A. Fadhil Lubis, "Pengembangan Studi Hukum Islam di IAIN," OASiS 1, no. 2 (Desember 2008): 292-93. 
receptie theory. This model is now followed by almost all law activists in Indonesia in addressing the existence of Islamic law. Even Ichtijanto presents a theory of existence as a function to strengthen receptio a contrario. ${ }^{13}$

\section{Religio-Ethics Model}

In this concept, Masykuri called it a group that supports the implementation of the moral ethics of religion and rejects the formalization and even involvement of religion in state life. ${ }^{14}$ it means that in this context, they did not want the state enters into religious affairs, whether private or collective, so it sets the various laws or regulations which banned people who do not agree with the contents of these rules, for them, let Islamic law run and apply according to the awareness of themselves.

Another term that illustrates this problem is the Deformalization of Islam, an effort to make Islam can not be understood as a ceremonial formal rite that is negated from ethics and benefit. Islam should be placed as a verb, not a noun so that the values of knowledge in it can be studied and reviewed in substance. Thus, deformalization means the de-institutionalization of the understanding of Islam as an official state mazhab, not as the tragedy of the mihnah (750-1258 AD) which injured the glory of the Abbasid Dynasty and the Caliph al-Makmun because it made the Mu'tazilites the official mazhab of thought at the time which gave birth to the glory of the Abbasid Dynasty and the Caliph al-Makmun because of disputes between Muslims and the state's justification in the name of religion, which also occurred in Indonesia. Under the pretext of upholding the country's sovereignty, the al-Makmun government conducted a screening of judicial officials, scholars, and governors in its territory. Those who oppose are dismissed from their posts, they are imprisoned and some are killed, one of them is Imam Ahmad bin Hanbal. ${ }^{15}$

\footnotetext{
${ }^{13}$ Ichtianto SA, Hukum Islam dan Hukum Nasional (Jakarta: Ind-Hill-Co, 1990), 86-87.

${ }^{14}$ Abdillah, "Wacana Formalisasi Syariat Islam," 7.

${ }^{15}$ Abdul Mu'ti, "Deformalisasi Islam: Aktualisasi Etik dan Maslahat dalam Beragama,"
} 
This thinking style has gone on nowadays, even though there are laws or legal rules that have been set by the state to be implemented by all its citizens, but they still do not want to implement it, for instance, marriage in Law No. 1 of 1974, Article 2 paragraph (2) Each marriage is recorded according to the applicable laws and regulations.

For them, marriages that are not recorded by the Registrar of Marriage are religiously valid, so there is no need for administrative registration. As a result, due to the average ulama has this kind of thinking, the dualism of understanding of the law emerges, that is, religiously valid and legally valid, for that, it is better to be religiously legitimate because it has an impact on matters of reward and sin than on the legal state. there is no impact on the ukhrawi.

The style of thought and application above has made the mazhab of fiqh the main guide, and it makes the fatwa a further guide. The entire contents of Islamic law have been summarized in the following two handbooks so that there is no need for instructions from the state which instead confuses the content of the religion they profess. This is where the role of the ulama, kiai, habib, or ustadz becomes very dominant in society, they are more trusting in the legal advice of the ulama rather than in the country's legal regulations. The assumption that is always sounded is that laws and others are not Islamic that need to be obeyed and implemented in public life.

\section{Convergence Model in Formalistic Cultural Based}

This third model is the ideal model that should be applied in Indonesia since legal theories base that law should originate from the bottom, where the conditions and main needs of the people are referred to others. However, on an implementation level, it seems far from the fire, the law was made without looking at the whole condition of its people, so sometimes it is ambiguous. Isn't Indonesia having millions 
of tribes and languages, as well as various beliefs and religions, and after the development of the times there have been many meetings and communication between cultures to form a new culture again, then whether plurality can not be a strong capital of this nation to create laws (legalization) that responsive?

This question is important to be raised because historically, the emergence of Law no. 1 of 1974 apparently could not be separated from the will of the palace, although in practice the modification was initiated through scientific discussions among scholars, academics, and religious judges. As a result, through a long journey in the enactment, there were laws which were then rejected in principle in the community, and even the people were happier to apply their fiqh law and get married under the hand or in a series, dividing family property before dying or even dividing inheritance with their respective cultural orders.

Regarding the case above, it is interesting to read the results of research in Gorontalo on the response of Muslim scholars about KHI, where the articles in KHI are not all acceptable, such as inheritance law (faräidh) in KHI that comes from fiqh books that are authoritative so that it can be accepted, but when it is included in the article of replacer heir, the Gorontalo scholar refused it because it was considered family from the Islamic fiqh pathway. ${ }^{16}$

It is important to know about local wisdom as it is very fundamental, and as all regions must have it, in the form of the culture of humanity, equality and impartiality, and culture of tolerance. Moreover, if this is related to the culture of Arab-Islamic acculturation with the local MalayIndonesian culture. Of course, all regions that have been addressed and penetrated by Islam must be familiar with the four elements above. Therefore, in creating responsive but also progressive laws must be based on the four cultural foundations above, understanding universally about

${ }^{16}$ Muchit A. Karim, "Respon Ulama dan Hakim Agama terhadap Fiqh Waris dan Kompilasi Hukum Islam di Gorontalo,” HARMONI 9, no. 36 (t.t.): 171-92. 
Law as a System, where legal norms cannot be realized without law enforcement, law enforcement will not be possible if it is not is part of a legal organization, while legal organizations cannot do anything without processes and procedures, while processes and procedures require facilities (physical and non-physical) which in turn require adequate funds. ${ }^{17}$

Therefore, the formation of law can not only be based on the thought of "legal logic", but also law as a system, the legal function is nothing but a mission about how the state must manage the life of the nation and state to achieve the vision in the constitution. As a result, thought and the formation and enforcement of the law inevitably constitute activities that are based on interdisciplinary processes, behaviors, and norms that are determined based on various results of a particular thought or science other than mere law. ${ }^{18}$

The normative guidelines above emphasize that culture and local wisdom are a part that must be integrated into every legal formation. The law must not only belong to the elitists so that the study becomes soaring and difficult to be grounded. The law must not be set up in the mind of the government without knowing the primary needs of the people and the cultural wisdom that lives in the community. What would happen to the law if it only became part of the country's archives that were piled up in warehouses and were never able to be implemented in the community, or if it could be implemented it might be only a few parts that were felt would not burden their psychology, mind, and life.

In this case, progressivity does not mean breaking out of legal norms, but it must be able to create synergy between modernity and culture, it means that intensive and solutive communication is needed in presenting such synergy before being codified in the form of laws

${ }^{17}$ Sunaryati Hartono, "Membangun Hukum Nasional Indonesia Menjadi Hukum yang Progresif dan Sesuai dengan Kebutuhan dan Tuntutan Masa Kini dan Masa Depan," dalam Dekonstruksi dan Gerakan Pemikiran Hukum Progresif (Yogyakarta: Thafa Media, 2013), 14.

${ }^{18}$ Hartono, 15. 
so that the community can accept voluntarily, even though there were small ripples that voiced rejection. Progressive and responsive law is born under (the community) and accommodated by the top (leader or government).

\section{Renewal Spirit of Islamic Law in Indonesia}

Renewal means that never existed before, has never been heard before, has never been used, never begun, fresh, and modern. ${ }^{19}$ A new thing usually feels fresher, as the local Arabic says al-jadid ladzidz (the new one is delicious). Therefore the term renewal can be interpreted to be new, replace with new, and modernize, based on the process, deeds, and ways to update. ${ }^{20}$ The renewal in Arabic called al-tajdìd, ${ }^{21}$ which means 'aks al-qadim (the opposite of old). in the Arabic dictionary, the word jadid is interpreted as something that becomes new. ${ }^{22}$

The use of the term jadid is found in the hadith of the authentic narration of Abū Daud from Abū Hurairah ra:

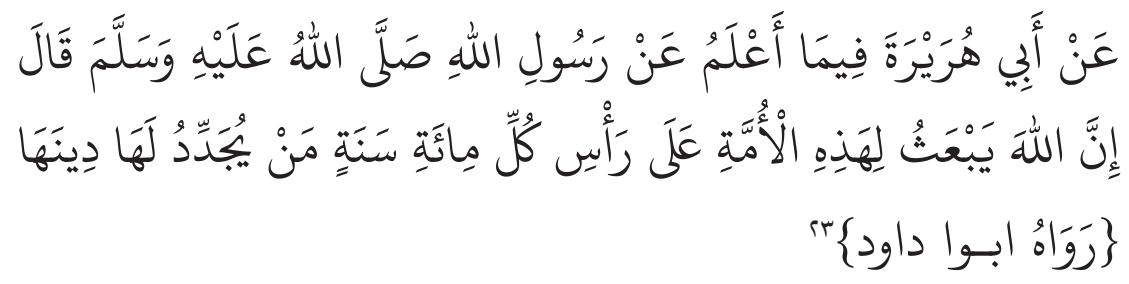

This means; From Abi Hurairah, What I have known the Prophet, sallahu alayhi wasallam, said; indeed Allah sent for these people at the end of every hundred years, a person who renews religion for him. (Narrated by Abū Daud)

\footnotetext{
${ }^{19}$ Departemen Pendidikan Nasional, Kamus Besar Bahasa Indonesia: Edisi Ketiga (Jakarta: Balai Pustaka, 2002), 96.

${ }^{20}$ Departemen Pendidikan Nasional, 96.

${ }^{21}$ M. Hidayat Nur Wahid, "Tajdid Sebagai Sebuah Harakah (Gerakan)," Jurnal Kajian Islam Márifah 2, no. 1 (1995): 28.

${ }^{22}$ Ibn al-Manzur, Lisan al-Arab, vol. III (Beirut: Dar al-Fikr, 1972), 111.

${ }^{23}$ Abu Dawud Sulaiman ibn al-Asy'ats ibn Ishaq al-Sajistani al-Azdi, Sunan Abu Dawud, vol. II (Mesir: Mushtafa al-Bab al-Halabi, 1955), 424.
} 
The quality of this hadith is strong as in the opinion of al-Baihaqi and al-Hakim (salaf scholars), as well as al-Hafiz Ibn Hajar al-Asqalani (khalaf scholars), ${ }^{24}$ also according to al-Albani. ${ }^{25}$ The interpretation of reform above if it is related to the term Islamic law, which means ijtihad to present Islamic law can answer various problems law according to his time to realize legal products that are always shalihun likulli of the era of a solution to whenever and wherever Islam. ${ }^{26}$

According to Hasbi, renewal have to move up to date, but not by denying religious arguments and not with an intention to cover up its purity, and not to destroy it either. ${ }^{27}$ Thus the renewal of Islamic law is justified, even the needs of Muslims, because of the different locus and wisdom contexts from the Islamic center. ${ }^{28}$

This consideration has a rational basis so that it can be received and appreciated by various countries outside Indonesia ${ }^{29}$ or other te The considerations are; (1) Locus of Indonesia and the Middle East are different; (2) Problems in Indonesia and the different times have more complex problems with the Islamic past. This consideration creates a decision to realize legal ijtihad following the context or personality of the Indonesian people. ${ }^{30}$

${ }^{24}$ Abi Tayyib Muhammad Syam al-Haq al-'Azhim Abadi, Awn al-Ma'bud Syarh Sunan Abi Dawud, vol. XI (Beirut: Dar al-Fikr, 1977), 396.

${ }^{25}$ Busthami Muhammad Sa'ad, Reaktualisasi Ajaran Islam; Pembaruan Agama Visi Modernis dan Pembaruan Agama Visi Salaf (Mafhum Tajdid ad-Din) (Jakarta: Minaret, 1987), 50 .

${ }^{26}$ Imam Syaukani, Rekonstruksi Epistemologi Hukum Islam Indonesia dan Relevansinya Bagi Pembangunan Hukum Nasional (Jakarta: RajaGrafindo Persada, 2006), 21-22.

${ }^{27}$ Nouruzzaman Shiddiqi, Figh Indonesia: Penggagas dan Gagasannya, Biografi, Perjuangan dan Pemikiran Teungku Muhammad Hasbi Ash Shiddieqy (Yogyakarta: Pustaka Pelajar, 1997), 81-82.

${ }^{28}$ Abdul Halim, "Ijtihad Kontemporer: Kajian Terhadap Beberapa Aspek Hukum Keluarga Islam Indonesia," dalam Madzhab Jogja: Menggagas Paradigma Ushul Figh Kontemporer (Yogyakarta: Al-Ruzz Press, 2002), 231. See Abdul Qodir Zaelani, "Konsep Ta’aqquli dan Ta’abbudi dalam Konteks Hukum Keluarga Islam”, Asas: Jurnal Hukum Ekonomi Syariah 6, no 1 (2014): 46-56.

${ }^{29}$ Asni, Pembaruan Hukum Islam di Indonesia: Telaah Epistemologis Kedudukan Perempuan dalam Hukum Keluarga (Jakarta: Direktorat Pendidikan Tinggi Islam Direktorat Jenderal Pendidikan Islam Kementerian Agama RI, 2012), 46. Compare Abdul Qodir Zaelani, "Pembaruan Hukum Keluarga: Kajian atas Sudan - Indonesia”, al-Adalah 10, no. 1 (2012): 331-342.

${ }^{30}$ Hasbi ash-Shiddieqy, Syariat Islam Menjawab Tantangan Zaman (Yogyakarta: IAIN Sunan Kalijaga, 1961), 24. 
Muslim law remains one of the great legal systems of the modern world, dealing with human affairs of a total Muslim population in various countries of over 500 million people. ${ }^{31}$

The production of Islamic law reform that has been implemented in various Muslim countries are:

1. Takhshish al-Qadhä (confirms the court's ruling).

2. Takhayyur (selection of various fiqh opinions).

3. Reinterpretation (reinterpretation relevantly).

4. Siyāsah Syar'iyyah (a country as a tool for determining legal policy to make it applied by its citizens).

5. Court decisions that can accommodate the tradition of customary law. ${ }^{32}$

Amir Syarifuddin also gave his categorization in the form of administrative policies, additional rules, talfì $q$, reinterpretation, and reformulation of legal products that are no longer actual ${ }^{33}$ While the grouping, according to Khoiruddin Nasution they are intra-doctrinal reform and extra-doctrinal reform. ${ }^{34}$

These models have become a milestone in Muslim countries in reforming Islamic law, including Indonesia, which has been explained in the previous chapter, the concept of Islamic legal reform as a form of the evolution of legal culture, is carried out through the formation of laws (taqnin). Rosemary Hunter and Richard Johnstone explain:

"Contemporary law reform processes often reflect the pluralist model of legal change. The government generally refer social questions or potentially controversial issues to a parliamentary committee or a statutory Law Reform Commission, which will then consult widely in formulating legislative proposals." ${ }^{35}$

${ }^{31}$ Rene David dan John E.C. Brierley, Major Legal Systems in the World Today: An Introduction to the Comparative Study of Law (London: Stevens \& Sons, 1985), 466.

${ }^{32}$ Norman Anderson, Law Reform in The Muslim World (London: The Athlone Press, 1976), 43-82.

${ }^{33}$ Amir Syarifuddin, Meretas Kebekuan Ijtihad: Isu-isu Penting Hukum Islam Kontemporer Indonesia (Jakarta: Ciputat Press, 2005), 77-80.

${ }^{34}$ Khoiruddin Nasution, "Metode Pembaruan Hukum Keluarga Islam Kontemporer," UNISIA XXX, no. 66 (Desember 2007): 335.

${ }^{35}$ Rosemory Hunter dan Richard Johnstone, "Explaining Law Reform," dalam Thinking 
Nevertheless, the enactment of Islamic law (fiqh becomes qanün) is certainly affected the subject to the evolution law too, from an unwritten law based on Islamic acculturation and local culture, it becomes an unwritten relationship between Islamic politicians and the rulers. In the end, it creates a diverse mindset and models of interpretation between each party. According to M. Atho Mudzhar, the diverse mindset will present four types of products, namely; fiqh books, decisions of the Religious Courts, laws and regulations in Muslim countries, and fatwas of the ulama. ${ }^{36}$

The paradigm of thinking has underpinned Muslims in various parts of the world including Indonesia as an effort to reform the law, through the application of codification (al-taqnin), a view to living the objectives of Islamic law which provides benefits for humanity in the world and the hereafter. and able to be a solution to various problems in the community. ${ }^{37}$ In the context of family law, the results of new legal renewal efforts to limit the practice of polygyny, granting of talak rights in women, the necessity of the registration of a marriage, guarantee of rights for wives, and rights for children whose parents divorced. ${ }^{38}$ Here is the purpose of qanūn normatively:

1. Attending welfare;

2. Arranging people's lives peacefully;

3. Upholding justice;

4. Maintaining the needs of humanity so they won't be disturbed.

The construct of thinking seems to be a real proof of the high enthusiasm of the Indonesian in carrying out Islamic law renewal through

about Law: Perspectives on the History, Philosophy and Sociology of Law (Australia: Allen \& Unwin, 1995), 136.

${ }^{36}$ M. Atho Mudzhar, "Pengaruh Faktor Sosial Budaya terhadap Produk Pemikiran Hukum Islam,” Jurnal Mimbar Hukum, 1991, 21-30.

${ }^{37}$ Iskandar Usman, Istihsan dan Pembaruan Hukum Islam (Jakarta: RajaGrafindo Persada, 1994), 116-17.

${ }^{38}$ Abdul Halim Barkatullah dan Teguh Prasetyo, Hukum Islam Menjawab Tantangan Zaman yang Terus Berkembang: Membahas Perkembangan Hukum Islam, Hukum Keluarga Islam, Hukum Ekonomi Islam, Hukum Pidana Islam (Yogyakarta: Pustaka Pelajar, 2006), 136. 
constitutional channels, such as Law 1/74 concerning Marriage and Presidential Instruction 1/91 concerning Compilation of Islamic Law. Constitution 38/99 concerning Management of Zakat, Constitution 41/04 concerning Waqf. Law 34/09 concerning the Organization of Hajj, and Law 21/08 on Sharia Banking. The spirit of renewal of Islamic law has increasingly gained a place on Indonesian earth with the birth of the Constitutional Court (red. MK) which is one of the progressive products of the 20th century.

One positive evidence of the establishment of the Constitutional Court for the renewal of Islamic law in the context of family law is the decision of the Constitutional Court No. 46 / PUU-VIII / 2010 which grants to Article 43 paragraph 1 of the Marriage Law, where children who are born out of wedlock have civil relations with their mother and mother's family and with a man as his or her father which can be proven based on science and technology or other evidence according to the law which has blood relations, including civil relations with his father's family.

The argument built on the ruling because a child is not only has a legal relationship based on marriage but also he/she goes through a blood relationship test (DNA test) with his parents. Therefore, a child is obliged to get legal protection from the state for the survival of a child, because if not, a child will always get the title "illegitimate child" even though there is no sin for the child for his parents' bad deeds.

The next case that is also interesting is a request from a group of University of Indonesia students to test the Marriage Law on the 1945 Constitution about the prohibition of interfaith marriages. For them, the contents of article 2 paragraph 1 of Law 1/74 concerning marriage has obstructed the constitutional rights of Indonesian citizens to conduct marriages of different religions, even though destiny is God's secret. For this reason, they ask that the conscience of every human being who happens to be a part of Indonesian citizens can choose their respective partners without being hindered by the state because an obstruction is 
very contrary to the 1945 Constitution because does not have binding legal power. ${ }^{39}$ But in the end, the material test was rejected by the Constitutional Court.

\section{Conclusion}

Through the narration above, it can be drawn, in which the application of Islamic law has taken place since the entry of Islam into the archipelago as a living law, and also since Islamic rule was established in some areas such as the Kingdom of Mataram with Islamic law applied as a milestone. All changed after the arrival of the invaders - including the Dutch - who was not only carried a fleet of war but also brought their religious teachings and laws so that their Muslin scholars had to make a formula of thinking to make the people would deign to accept their laws with renewal efforts. This effort was used until Indonesia was established and pledged its independence from Dutch colonialism, so that when the founders of the nation began to formulate the concept of the state, a debate arose between Islamic groups who wanted to fully implement Islamic law and nationalist groups who rejected it.

After Indonesia became independent, there were three models for the implementation of Islamic law in Indonesia, including the spirit of renewal in them, they are; formalistic model which formulates and creates various formal laws to be applied by all Indonesia citizens, especially for Muslims; religio-ethics model that supports the implementation of the moral ethics of religion and rejects the formalization, moreover involvement of religion in state life, in this context, they do not want the state's role at all in religious affairs, whether private or collective, thus create various laws or regulations that restrain people who do not agree with the contents of these rules, for them, let Islamic law run and apply in accordance with the awareness of the people themselves,

${ }^{39}$ Febrian, "Mengapa Pernikahan Beda Agama Digugat ke MK?," diakses 30 September 2014, http://nasional.kompas.com. 
and the convergence model, which is a cultural-based formalistic model, where law comes from below in the context of the conditions and the main needs of the people being referred to, so that the formalized regulation experiences constraints and moves back partially, such as creating the Law on Zakat, Waqf, Hajj, and others, and also the material test track in the Constitutional Court.

\section{References}

Abadi, Abi Tayyib Muhammad Syam al-Haq al-Azhim. Awn al-Ma'bud Syarh Sunan Abi Dawud. Vol. XI. Beirut: Dar al-Fikr, 1977.

Abdillah, Masykuri. "Wacana Formalisasi Syariat Islam." Dalam Formalisasi Syariat Islam di Indonesia: Sebuah Pergulatan yang Tak Pernah Tuntas. Jakarta: Renaisan, 2007.

Anderson, Norman. Law Reform in The Muslim World. London: The Athlone Press, 1976.

Arifin, Bustanul. "Membangun Ilmu Hukum Indonesia." Dalam Hukum Islam di Indonesia: Perspektif Muhammadiyah dan NU. Jakarta: Universitas Yarsi, 1999.

Asni. Pembaruan Hukum Islam di Indonesia: Telaah Epistemologis Kedudukan Perempuan dalam Hukum Keluarga. Jakarta: Direktorat Pendidikan Tinggi Islam Direktorat Jenderal Pendidikan Islam Kementerian Agama RI, 2012.

Asshiddiqie, Jimly, dan Ali Safa'at. Teori Hans Kelsen tentang Hukum. Jakarta: Sekretariat Jenderal \& Kepaniteraan Mahkamah Konstitusi RI, 2006.

Azdi, Abu Dawud Sulaiman ibn al-Asy'ats ibn Ishaq al-Sajistani al-. Sunan Abu Dawud. Vol. II. Mesir: Mushtafa al-Bab al-Halabi, 1955.

Barkatullah, Abdul Halim, dan Teguh Prasetyo. Hukum Islam Menjawab Tantangan Zaman yang Terus Berkembang: Membahas Perkembangan Hukum Islam, Hukum Keluarga Islam, Hukum Ekonomi Islam, Hukum Pidana Islam. Yogyakarta: Pustaka Pelajar, 2006.

David, Rene, dan John E.C. Brierley. Major Legal Systems in the World 
Today: An Introduction to the Comparative Study of Law. London: Stevens \& Sons, 1985.

Departemen Pendidikan Nasional. Kamus Besar Bahasa Indonesia: Edisi Ketiga. Jakarta: Balai Pustaka, 2002.

Febrian. "Mengapa Pernikahan Beda Agama Digugat ke MK?” Diakses 30 September 2014. http://nasional.kompas.com.

Halim, Abdul. "Ijtihad Kontemporer: Kajian Terhadap Beberapa Aspek Hukum Keluarga Islam Indonesia.” Dalam Madzhab Jogja: Menggagas Paradigma Ushul Fiqh Kontemporer. Yogyakarta: Al-Ruzz Press, 2002.

Hartono, Sunaryati. "Membangun Hukum Nasional Indonesia Menjadi Hukum yang Progresif dan Sesuai dengan Kebutuhan dan Tuntutan Masa Kini dan Masa Depan.” Dalam Dekonstruksi dan Gerakan Pemikiran Hukum Progresif. Yogyakarta: Thafa Media, 2013.

Hunter, Rosemory, dan Richard Johnstone. "Explaining Law Reform." Dalam Thinking about Law: Perspectives on the History, Philosophy, and Sociology of Law. Australia: Allen \& Unwin, 1995.

Kansil, C.S.T. Pengantar Ilmu Hukum dan Tata Hukum Indonesia. Jakarta: Balai Pustaka, 1992.

Karim, Muchit A. "Respon Ulama dan Hakim Agama terhadap fiqh Waris dan Kompilasi Hukum Islam di Gorontalo." HARMONI 9, no. 36 (t.t.): Desember 2010.

Kelsen, Hans. General Theory of Law and State. New York: Reissued, 1961. Krissantono (ed.). Pandangan Presiden Soeharto tentang Pancasila. Jakarta: Yayasan Proklamasi CSIS, 1980.

Lubis, Nur A. Fadhil. "Pengembangan Studi Hukum Islam di IAIN." OASiS 1, no. 2 (Desember 2008).

Maftukhatusolikhah. "Qanunisasi Hukum Islam: Suatu Tinjauan Filsafat Hukum.” Medina-Te 3, no. 1 (Juni 2007): 2.

Manzur, Ibn al-. Lisan al-Arab. Vol. III. Beirut: Dar al-Fikr, 1972.

Mudzhar, M. Atho. "Pengaruh Faktor Sosial Budaya terhadap Produk Pemikiran Hukum Islam.” Jurnal Mimbar Hukum, 1991. 
Mustafa, Bachsan. Sistem Hukum Indonesia. II. Bandung: Remadja Karya, 1985.

Mustaqim, Muhammad. "Fundamentalisme Islam dan Tantangan NegaraBangsa (Nation-State)." Jurnal Abidin Media Dielektika Ilmu Islam 3, no. 2 (Desember 2011).

Mu'ti, Abdul. "Deformalisasi Islam: Aktualisasi Etik dan Maslahat dalam Beragama." Dalam Islam Madzhab Tengah: Persembahan 70 Tahun Tarmizi Taher. Jakarta: Grafindo Khazanah Ilmu, 2007.

Nasution, Khoiruddin. "Metode Pembaruan Hukum Keluarga Islam Kontemporer." UNISIA XXX, no. 66 (Desember 2007).

—. Pengantar Studi Islam. Yogyakarta: Tazzafa+ACAdeMIA, 2012.

Rajafi, Ahmad. "Inkulturasi Wahyu dan Budaya Lokal Serta Implikasinya Terhadap Pembaharuan Hukum Keluarga di Indonesia.” Disertasi, IAIN Raden Intan Lampung, 2015.

—. "Islam dan Kearfian Lokal: Pembaruan Hukum Keluarga di Indonesia Model Inkulturasi Wahyu dan Budaya Lokal.” Akademika: Jurnal Pemikiran Islam 21, no. 1 (Juni 2016): 73.

SA, Ichtianto. Hukum Islam dan Hukum Nasional. Jakarta: Ind-Hill-Co, 1990.

Sa'ad, Busthami Muhammad. Reaktualisasi Ajaran Islam; Pembaruan Agama Visi Modernis dan Pembaruan Agama Visi Salaf (Mafhum Tajdid ad-Din). Jakarta: Minaret, 1987.

Shiddieqy, Hasbi ash-. Syariat Islam Menjawab Tantangan Zaman. Yogyakarta: IAIN Sunan Kalijaga, 1961.

Shiddiqi, Nouruzzaman. Figh Indonesia: Penggagas dan Gagasannya, Biografi, Perjuangan dan Pemikiran Teungku Muhammad Hasbi Ash Shiddieqy. Yogyakarta: Pustaka Pelajar, 1997.

Syarifuddin, Amir. Meretas Kebekuan Ijtihad: Isu-isu Penting Hukum Islam Kontemporer Indonesia. Jakarta: Ciputat Press, 2005.

Syaukani, Imam. Rekonstruksi Epistemologi Hukum Islam Indonesia dan Relevansinya Bagi Pembangunan Hukum Nasional. Jakarta: RajaGrafindo Persada, 2006. 
Usman, Iskandar. Istihsan dan Pembaruan Hukum Islam. Jakarta: RajaGrafindo Persada, 1994.

Wahid, M. Hidayat Nur. "Tajdid Sebagai Sebuah Harakah (Gerakan)." Jurnal Kajian Islam Márifah 2, no. 1 (1995).

Zaelani, Abdul Qodir. "Pembaruan Hukum Keluarga: Kajian atas Sudan, Indonesia", al-Adalah 10, no. 1 (2012).

- "Konsep Ta’aqquli dan Ta’abbudi dalam Konteks Hukum Keluarga Islam”, Asas: Jurnal Hukum Ekonomi Syariah 6, no 1 (2014). 